\title{
ACRL in the 1990s \\ Racing toward tomorrow on the information super highway
}

t's impossible to reflect on the 1990s

without noting the changes that began across the world in 1989 with the fall of the Berlin Wall and the subsequent dissolution of the Soviet Union. At the very beginning of 1990, Nelson Mandela was freed from prison in South Africa, and, just a few years later, became the president of a country without apartheid. Germany's reunification also served to underscore how different the international politics of the $1990 \mathrm{~s}$ would be. In Asia the crackdown on protesters in $\mathrm{Ti}$ ananmen Square in

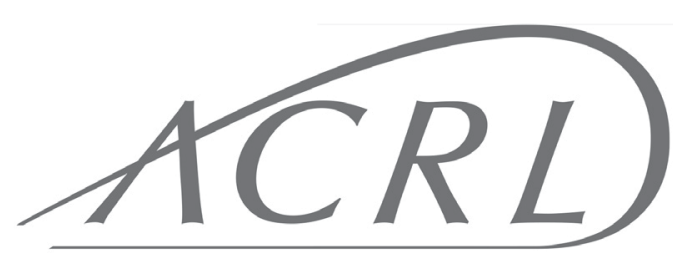

75 TH ANNIVERSARY
Association of College \& Research Libraries A DIVISION OF THE AMERICAN LIBRARY ASSOCIATION introduction of a nascent "Internet" in the form of the National Research and Education Network (NREN) and the Information Super Highway.

The debate over whether libraries should focus on ownership or access to collections heated up with the continued growth in the price of scholarly communication, combined with a seemingly pervasive decrease in library budgets running parallel to the technological means to more easily access and share electronic collections.

Academic liBeijing seemed contradictory at a time when freedom of speech was growing in other parts of the world.

Technology also seemed to be on the fast track as academic libraries sped up their adoption of resources in new formats and access through different mediums. At the beginning of the decade some, but not all, university and college libraries touted the shift of their catalogs from card to online, and the question remained whether e-journals would replace print.

For our patrons the decade was marked by continued growth of the personal computer industry and the braries continued to provide hubs for computing on college campuses, and many academic libraries began to incorporate computers and information literacy into what had previously been bibliographic instruction. Facilities also began to reflect the "café style" bookstores that ironically seemed to be doing their best to mimic the feel of traditional libraries.

Frederick D. Barnhart is associate dean for library services and collections at Loyola University-Chicago, email: fbarnha@luc.edu

() 2015 Frederick D. Barnhart 
During the decade, ACRL maintained its status as the largest division within ALA, and increased its membership more than $6 \%$, from 10,639 to 11,297 . ACRL continued to work with ALA throughout the 1990 s to partner on initiatives of importance to membership, especially those related to the availability of information resources, the creation of online networks, and the revision of copyright law. The passage of the High Performance Computer Act, which authorized the creation of the NREN, and galvanized ACRL's role as an advocate for a free and open information infrastructure.

The NREN initiative took on greater momentum as numerous witnesses from both higher education institutions and library organizations, including ACRL, advocated for greater access for schools, public libraries, and museums to the National Science Foundation Network (NSFNET). Senator Albert Gore Jr. (DTenessee) spoke at an ALA Midwinter Meeting and influenced both ALA and ACRL attendees with his vision of the potential benefits of NSFNET.

The White House Conference on Library Information Services in July 1991 was attended by ACRL representatives, who advocated for an "information superhighway" similar to NREN. Support would hopefully include funding and support for libraries, including governmental libraries, services for multicultural and multilingual populations, copyright reform, intellectual freedom, and, wherever possible, the elimination of physical barriers within libraries.

In 1992, the "Conference Circuit" column in CERL News, highlighted the inclusion of liaison relationships with other higher education organizations. This continued in 1996 with the "ACRL Partners in Higher Education" column, which formalized reports from liaisons to other organizations.

As hoped, the ongoing relationships with CNI, EDUCOM, CAUSE, and ARL

\section{Facilities also began to reflect the "café style" bookstores that ironi- cally seemed to be doing their best to mimic the feel of traditional libraries.}

served to enrich the ACRL membership with discussion of technologies whose possibilities were only just beginning to be imagined.

At the same time, concerns about the importance of the association's Faculty Status to Academic Librarians, and ACRL membership in general, created a push for action by ACRL leadership resulting in a sponsored think tank on faculty status and the revision of standards for faculty status for college and university librarians (first approved in 1971). In addition to networking and professional development, the ability to participate effectively in the electronic environment was added to the priorities for ACRL.

In 1993, CERL News began offering a popular column dedicated to locating and using discipline-specific resources through the Internet. Terms such as Gopher and Telnet briefly entered the academic librarian vocabulary.

The mid-1990s also saw the development of a new ACRL strategic plan with four main goals: 1) to provide developmental activities for academic and research librarians, 2) to collaborate with other professional organizations in higher education in order to promote mutual interests, 3) to become actively involved in information policy at a national level, and 4) to ensure that ACRL operates efficiently.

The Council of Liaisons was created as part of the outreach to other professional organizations, including groups such as the American Association of Higher Education, American Association of Community Colleges, American 
Council on Education, and Association of American Colleges and Universities, to name but a few.

The 1997 ACRL National Conference invited academic librarians to reflect on the future in a variety of ways, as well, such as in roundtable sessions where speculation was encouraged.

One look forward came from the keynote by Cornel West in which he asked, "Will we survive?" and answered, "Yes. How depends on what we do."

In response to a vision of future need for library services, the Extended Academic Library Services Guidelines were updated, addressing the need for library collections and services to be universally available to the extended academic community.

ACRL advocated on behalf of academic librarians and higher education users as both the Next Generation Internet Initiative and the Digital Millennium Copyright Act, along with other important information-related legislation, worked its way to U.S. Congress.

As the decade, the century, and the millennium all came to a close, the 1999 ACRL National Conference was held in Detroit with the theme of "Racing Toward Tomorrow." Copyright, scholarly communication, and student learning using the Internet were hot topics at the conference, which attracted 3,000 attendees. In stark contrast to the beginning of the decade, those who missed the conference could view the keynote on their personal computers via the web.

Fortunately, and contrary to some predictions, the world did not end, and the party continued past midnight on December 31, 1999. n

"Catching up with time" (continues from page 365)

have three months to relocate. Two weeks into the renovations, this was changed to one week. Instead of panicking, we quickly accessed our available space to meet the new deadline.

Tip: Be aware that "It Happens!" Be ready to address issues as they arise, and remain calm if or when they do. Unforeseen problems often disrupt the best laid plans. Construction generates noise, dust, and odors that can be disruptive to your environment. Minimize these by creating barriers between the construction and your library community. It may be necessary to relocate staff members who may not be able to work in close proximity to the renovated areas. Be ready to improvise quickly.

12. Plan for future renovations. After the completion of our renovations, we realized that we should have considered our egress on Level 2. We have placed that item on the top of our wish list for the next phase of planning.
Tip: You will discover that although your initial plan was well thought out, some things were overlooked. Use this to begin your planning for any future changes.

\section{Conclusion}

The renovations have changed the library building from a place of quiet individual study into a dynamic collaborative learning and research unit that provides access to the latest technology. As another phase of renovations is planned, BRL will continue to update its facilities to further bring its building into the next evolution in the state-of-the-art for academic libraries. The lessons we learned during the first phases will help to guide us as we do.

\section{Note}

1. "Cuomo leads fanfare at new, $\$ 60$ million academic library," American Libraries, 19, no. 9: 741 . 